\title{
Индикаторная система на основе наночастиц диоксида церия
}

\author{
Боброва Д.В. \\ Химия \\ 9 класс, ГБОУ Школа № 1575, г. Москва,
}

Научный руководитель: Чопорова Ж.В., ГБОУ Школа № 1575, г. Москва,

В процессе работы был получен коллоидный раствор наночастиц диоксида церия и на его основе создана индикаторная система. Она включает в себя тест полоски и шкалу. На основе данного индикатора можно определить наличие и процентное содержание перекиси водорода в антисептиках, в зубной пасте и т.д. Ключевые слова: наночастицы диоксида церия, перекись водорода, индикатор

Тема достаточно актуальна. В связи с пандемией ковида ВОЗ были рекомендованы антисептики с содержанием перекиси водорода [1]. А содержат ли перекись водорода наши повседневные антисептики? Чтобы ответить на этот вопрос нужен индикатор. Таким индикатором могли бы стать фильтровальные бумажки, пропитанные раствором наночастиц диоксида церия. В литературе описана способность наночастиц диоксида церия окрашивать соединения с перекисью водорода [2-4]. Новизна работы в том, что такие тест полоски на основе наночастиц диоксида церия ещё не созданы.

Целью данной работы является создание индикаторной системы на основе наночастиц диоксида церия.

Предмет исследования : наночастицы диоксида церия

\section{Задачи:}

1. Получить коллоидный раствор наночастиц диоксида церия .

2. Пропитать фильтровальную бумагу.

3. Создать индикаторную шкалу.

4. Исследовать на содержание перекиси водорода бытовые антисептики и сравнить их с изготовленным антисептиком по рецепту ВОЗ. 
5. Исследовать на содержание перекиси водорода отбеливающие зубные пасты.

\section{Методики и эксперименты}

\section{Получение наночастиц диоксида церия [5].}

5 мл кристаллогидрата сульфата церия, растворили в 10 мл дистиллированной воды, затем постепенно, по полмиллилитра, добавляли 10\%-ный водный раствор аммиака. Постепенно при добавлении водного раствора аммиака (до 2-х мл) он приобрёл белёсый цвет. Луч лазера, пропущенный сквозь раствор с наночастицами, дал эффект Тиндаля. Следовательно, был получен коллоидный раствор наночастиц.

При добавлении перекиси водорода раствор в пробирке приобрёл сначала светло-оранжевый, а затем тёмно-морковный оттенки, что свидетельствует об образовании окрашенных пероксидных соединений церия.

\section{Получение индикаторной бумаги}

Обильно пропитали фильтровальную бумагу суспензией и подсушили. Чтобы волокна бумаги удерживали много частиц внутри толщины бумаги, повторили пропитывание три раза.

\section{Создание индикаторной шкалы}

На различные куски индикаторной бумаги нанесли перекись водорода $(5 \%, 3 \%$, $2,5 \%, 1,5 \%, 0,5 \%)$. Получили разные оттенки (от бледно-жёлтого до багровокирпичного). Бумага не реагировала цветом на воду и спирт.

Методика проверки антисептиков на содержание перекиси водорода. На чистые белые листы бумаги положили индикаторные полоски и пропитали их различными антисептиками. Из антисептиков выбрали разные виды: обычный антисептик для рук, хлоргексидин, антисептик, рекомендованный Роспотребнадзором, кожный антисептик (Германия), дезинфицирующий спрей. Приготовили антисептик по рецепту ВО3 (по объёму - на 1 часть глицерина, 3 части $3 \%$ ой перекиси водорода и 57 частей этанола). Наблюдали различное по цвету окрашивание индикаторной бумаги. 
Методика проверки отбеливающих зубных паст на содержание перекиси водорода.

На индикаторные полоски нанесли отбеливающее зарубежное средство для зубов (в составе есть перекись водорода), обычную зубную отбеливающую пасту на травах, отбеливающий гель для зубов, содержащий большой процент перекиси водорода в составе. Получили разные оттенки окраски индикаторной бумаги.

\section{Результаты}

1. Протекание реакции при получении коллоидного раствора наночастиц диоксида церия. ( Рис.1-4)

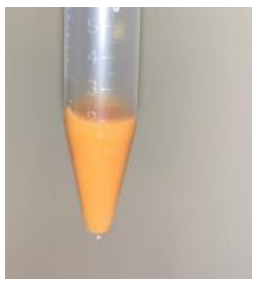

Рис. 1
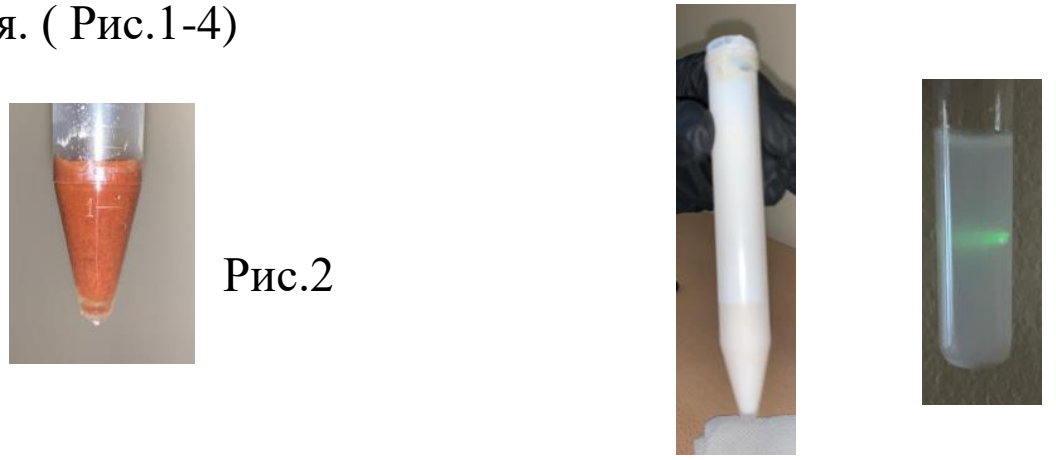

Рис. 3 Рис. 4

2. Создана индикаторная бумага - тест полоски, бумага не реагировала цветом на воду и этиловый спирт.

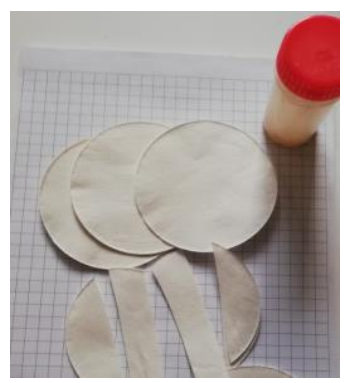

Рисунок 5. Индикаторные тест полоски

3. Создана индикаторная шкала рис.6

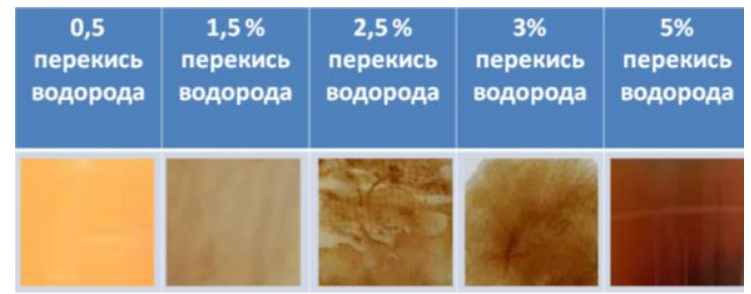


Рис.6. Индикаторная шкала

4. Исследование показало, что антисептики, рекомендованные Роспотребнадзором и импортные, содержат в своём составе перекись водорода, а обычные бытовые - нет.

5. Исследование показало, что только импортные отбеливающие зубные средства содержат перекись водорода, в составе она указана.

\section{Выводы}

Исследована и показана возможность создания индикаторной бумаги на основе наночастиц диоксида церия. Таким образом, с использованием полученной индикаторной системы можно полуколичественно определять концентрацию перекиси водорода, в том числе, в антисептиках, содержащих воду и спирт. Реакция окрашивания перекисью является специфической для соединений церия и достаточно чувствительной, чтобы определять разбавленные растворы перекиси водорода.

\section{Список литературы}

1. Рекомендованные ВОЗ рецептуры антисептиков для рук// документ с сайта https://substa.ru/antiseptik-dlya-ruk-reczept-po-rekomendaczii-voz -2020- c.1$\underline{9}$.

2. Химическая

энциклопедия, https://gufo.me/dict/chemistry encyclopedia/\%D0\%B8\%D0\%BD\%D0\%B4\% D0\%B8\%D0\%BA\%D0\%B0\%D1\%82\%D0\%BE\%D1\%80\%D1\%8B, дата обращения к сайту 10.12.2020

3. Википедия. Химические индикаторы, сайт https://ru.wikipedia.org/wiki/\%D0\%A5\%D0\%B8\%D0\%BC\%D0\%B8\%D1\%8 7\%D0\%B5\%D1\%81\%D0\%BA\%D0\%B8\%D0\%B5 \%D0\%B8\%D0\%BD\%D0 

дата обращения 27.11.2020.

4. Жилин Д.М., Индикаторы в современной химии // Химия в школе // - 1997. - N5.- C.9-15.

5. Тест полоски на перекись водорода, сайт https://artmedika.com/catalog/Lab.supplies/indikator/product-7188.html , дата обращения 8.12.2020

6. Щербаков А.Б. [и др.]. Наноматериалы на основе диоксида церия : свойства и перспективы использования в медицине // Биотехнология.2011- т.4, № 1 .

7. Иванов В.К. [и др.].Необычные свойства диоксида кремния// Природа.2011 - № 3.- c. 47-57.

8. Иванов В.К. [и др.]. Структурно_чувствительные свойства и биомедицинские применения нанодисперсного диоксида церия // Успехи химии. — 2009. —т. 78, №9. — с. 924-941.

9. Щербаков А. Б., Иванов В. К. Практикум по наноматериалам и нанотехнологиям. -М.: Издательство Московского Университета, 2019; 